\title{
Identification and typing of pyogenic streptococci by enzyme electrophoretic polymorphism
}

\author{
F. BERT*, B. PICARD, N. LAMBERT-ZECHOVSKY and P. GOULLET
}

Laboratoire de Microbiologie, Faculté de Médecine Xavier-Bichat (Université Paris VII), 16 rue Henri Huchard, 75018 Paris, France

\begin{abstract}
Summary. Polyacrylamide-agarose gel electrophoresis was used to study polymorphism of lactate dehydrogenase (LDH), nucleoside phosphorylase (NSP), phosphoglucose isomerase (PGI), hydroxybutyrate dehydrogenase (HBD), adenylate kinase (ADK) and esterases of 44 strains of Streptococcus pyogenes, 25 group G streptococcal strains, 11 "S. equisimilis" strains, seven $S$. dysgalactiae strains, four $S$. canis strains, three $S$. equi strains and seven $S$. zooepidemicus strains. Analysis of LDH, NSP, PGI, HBD and ADK provided valuable interspecies differentiation, by showing that four groups of strains corresponded to the four known DNA homology groups. Esterases showed greater intraspecies variation than the other enzymes. The combined analysis of the six enzymes indicated 31 zymotypes among $S$. pyogenes, 14 in group G streptococci and 11 in "S. equisimilis" strains. This was shown to be an effective technique for typing pyogenic streptococci.
\end{abstract}

\section{Introduction}

Since the description of group-specific antigens by Lancefield $^{1}$ the classification of streptococci has mainly relied on serological grouping; serological groups were often regarded as distinct species. Although this technique is a useful and simple tool for distinguishing pathogenic $\beta$-haemolytic streptococci, its taxonomic value is limited because it provides no information on the genetic relationships among species. Moreover, many strains of streptococci cannot be typed by this technique. Other classifications have been based on physiological and biochemical characters ${ }^{2}$ and numerical taxonomic studies. ${ }^{3}$ DNADNA and DNA-rRNA hybridisation studies indicate that the term pyogenic streptococci should be confined to strains of serological groups A, C, G (large colony type) and L, and includes five species, Streptococcus pyogenes, $S$. dysgalactiae, $S$. canis, $S$. equi and $S$. iniae . $^{4-6}$ According to these studies, strains designated "S. equisimilis" and streptococci of serological groups $\mathrm{G}$ and $\mathrm{L}$ belong to the species $S$. dysgalactiae. Strains designated $S$. zooepidemicus are genetically similar to $S$. equi and should be reclassified as $S$. equi subsp. zooepidemicus, thereby automatically creating $S$. equi

Received 12 Dec. 1994; accepted 15 Dec. 1994

* Address for correspondence: Hôpital Beaujon, Service de Microbiologie, 100 Bd du Général Leclerc, 92118 Clichy Cedex, France. subsp. equi. The findings of these studies are inconsistent with the serological classification since they bring together strains of distinct serological groups and separate strains belonging to the same group. They also conflict with the results of a numerical study that included "S. equisimilis" and S. zooepidemicus in a single phenon. ${ }^{3}$ Such discrepancies emphasise the continuing confusion over the taxonomic relationships among and within these species.

In the late 1980 s, there was an upsurge in the worldwide incidence of severe infections with $S$. pyogenes, including toxic-shock-like syndrome and acute rheumatic fever. ${ }^{7,8}$ This emphasises the need for increased epidemiological and basic laboratory research in this field. Most epidemiological studies on group A streptococcal infections have been based on serological typing of the $\mathrm{M}$ protein, often combined with that of the $\mathrm{T}$ protein and serum opacity factor antigen. ${ }^{9}$ The detection of $\mathrm{T}$ protein antigens is also a useful method for serotyping streptococci of groups $\mathrm{C}$ and $G,{ }^{10}$ but the cost and difficulty of preparing antisera mean that these techniques are restricted to a few reference laboratories. Furthermore, many $S$. pyogenes strains are M-non-typable, so more refined typing methods are required for further epidemiological studies. Ten biotypes of group A streptococci have been described and shown to be closely associated with serotypes. ${ }^{11}$ DNA analysis has been used for $S$. pyogenes typing, particularly restriction fragment length polymorphism (RFLP) analysis of total 
Table 1. Features of the streptococcal strains examined

\begin{tabular}{|c|c|c|c|c|}
\hline $\begin{array}{l}\text { DNA homology } \\
\text { group }^{6}\end{array}$ & $\begin{array}{c}\text { Species } \\
\text { (Lancefield group) }\end{array}$ & Strain code & Origin & Zymotype \\
\hline \multirow[t]{44}{*}{1} & \multirow{44}{*}{$\begin{array}{l}\text { S. pyogenes } \\
\text { (group A) }\end{array}$} & A4 & Scarlet fever & 1 \\
\hline & & 5502 & Throat & 2 \\
\hline & & 5750 & Pus & 3 \\
\hline & & CIP 5649 & Scarlet fever & 4 \\
\hline & & CIP 5650 & Throat & 4 \\
\hline & & CIP 5678 & Unknown & 5 \\
\hline & & CIP 5660 & Unknown & 6 \\
\hline & & 5800 & Ear & 6 \\
\hline & & 5723 & Pus & 7 \\
\hline & & CIP 5679 & Unknown & 8 \\
\hline & & CIP 5662 & Throat & 9 \\
\hline & & 5403 & Abscess & 10 \\
\hline & & CIP 54.5 & Unknown & 11 \\
\hline & & CIP 56.44 & Unknown & 11 \\
\hline & & CIP 70.3 & Pleural fluid & 11 \\
\hline & & CIP 56.52 & Throat & 12 \\
\hline & & 5837 & Wound & 13 \\
\hline & & 5538 & Abscess & 14 \\
\hline & & 5780 & Unknown & 15 \\
\hline & & A21 & $\begin{array}{l}\text { Throat (acute rheumatic } \\
\text { fever) }\end{array}$ & 16 \\
\hline & & CIP 56.45 & Unknown & 17 \\
\hline & & 5241 & Unknown & 18 \\
\hline & & 5402 & Pus & 19 \\
\hline & & 5524 & Abscess & 19 \\
\hline & & 5840 & Erysipelas & 19 \\
\hline & & 5778 & Wound & 20 \\
\hline & & 5358 & Wound & 21 \\
\hline & & 5542 & Wound & 22 \\
\hline & & 5726 & Abscess & 23 \\
\hline & & A 30 & Unknown & 24 \\
\hline & & CIP 56.61 & Acute rheumatic fever & 25 \\
\hline & & CIP 56.65 & Throat & 25 \\
\hline & & CIP 56.1 & Puerpueral fever & 26 \\
\hline & & CIP 56.42 & Scarlet fever & 26 \\
\hline & & CIP 56.54 & Unknown & 26 \\
\hline & & CIP 56.56 & $\begin{array}{l}\text { Throat (acute rheumatic } \\
\text { fever) }\end{array}$ & 26 \\
\hline & & CIP 56.59 & Scarlet fever & 26 \\
\hline & & CIP 56.64 & Scarlet fever & 26 \\
\hline & & CIP 56.53 & Unknown & 27 \\
\hline & & CIP 56.57 & $\begin{array}{l}\text { Throat (acute rheumatic } \\
\text { fever) }\end{array}$ & 28 \\
\hline & & CIP 56.47 & Throat & 29 \\
\hline & & CIP 56.66 & Unknown & 29 \\
\hline & & 5742 & Pus & 30 \\
\hline & & CIP 56.63 & $\begin{array}{l}\text { Throat (acute rheumatic } \\
\text { fever) }\end{array}$ & 31 \\
\hline \multirow[t]{24}{*}{2} & \multirow{24}{*}{$\begin{array}{l}\text { Streptococcus sp. } \\
\text { (group G) }\end{array}$} & & & \\
\hline & & 5404 & Pus & 34 \\
\hline & & 5712 & Throat & 35 \\
\hline & & 4002 & Blood & 36 \\
\hline & & G6 & Unknown & 37 \\
\hline & & G14 & Unknown & 38 \\
\hline & & 2987 & Blood & 38 \\
\hline & & 5362 & Throat & 38 \\
\hline & & 5544 & Wound & 38 \\
\hline & & 5706 & Ear & 38 \\
\hline & & 5990 & Pus & 38 \\
\hline & & 5942 & Pleural fluid & 39 \\
\hline & & 5578 & Pus & 40 \\
\hline & & 5748 & Trachea & 40 \\
\hline & & 5356 & Fistula & 41 \\
\hline & & 5357 & Pus & 41 \\
\hline & & 5500 & Pus & 41 \\
\hline & & 2329 & Blood & 42 \\
\hline & & 5539 & Wound & 42 \\
\hline & & 5622 & Trachea & 42 \\
\hline & & 5991 & Cerebrospinal fluid & 42 \\
\hline & & 5686 & Throat & 43 \\
\hline & & G4 & Unknown & 44 \\
\hline & & 5679 & Unknown & 45 \\
\hline
\end{tabular}


Table I (cont.)

\begin{tabular}{|c|c|c|c|c|}
\hline $\begin{array}{l}\text { DNA homology } \\
\text { group }^{6}\end{array}$ & $\begin{array}{c}\text { Species } \\
\text { (Lancefield group) }\end{array}$ & Strain code & Origin & Zymotype \\
\hline & \multirow{13}{*}{$\begin{array}{l}\text { "S. equisimilis" } \\
\text { (group C) }\end{array}$} & 5728 & Trachea & 47 \\
\hline & & 5031 & Blood & 51 \\
\hline & & 6069 & Unknown & 32 \\
\hline & & 6818 & Wound & 46 \\
\hline & & 5953 & Blood & 48 \\
\hline & & 5283 & Trachea & 51 \\
\hline & & 5753 & Trachea & 52 \\
\hline & & 6851 & Pus & 53 \\
\hline & & 6850 & Pus & 54 \\
\hline & & $\mathrm{ES} 2$ & Veterinary & 55 \\
\hline & & ES1 & Veterinary & 56 \\
\hline & & ES4 & Veterinary & 59 \\
\hline & & ES3 & Veterinary & 60 \\
\hline & \multirow{7}{*}{$\begin{array}{l}\text { S. dysgalactiae } \\
\text { (group C)* }\end{array}$} & CIP 55.123 & Unknown & 33 \\
\hline & & CIP 55.119 & Unknown & 49 \\
\hline & & CIP 55.120 & Unknown & 50 \\
\hline & & $\mathrm{C} 90$ & Unknown & 57 \\
\hline & & $\mathrm{C} 89$ & Unknown & 58 \\
\hline & & $\mathrm{C} 91$ & Unknown & 61 \\
\hline & & CIP 102914T & Unknown & 61 \\
\hline \multirow[t]{4}{*}{3} & S. canis & CAN1 & Veterinary & 62 \\
\hline & (group $\mathbf{G}$ ) & CIP 103223 & Bovine mastitis & 63 \\
\hline & & CAN2 & Veterinary & 63 \\
\hline & & CAN3 & Veterinary & 63 \\
\hline \multirow[t]{10}{*}{4} & S. equi & EQ1 & Veterinary & 64 \\
\hline & (group C) & $\mathrm{EQ} 2$ & Veterinary & 64 \\
\hline & & CIP 102910T & Unknown & 65 \\
\hline & S. zooepidemicus & $\mathrm{Z4}$ & Veterinary & 66 \\
\hline & (group C) & 5374 & Blood & 67 \\
\hline & & Z3 & Veterinary & 68 \\
\hline & & $\overline{\mathrm{Z}} 1$ & Veterinary & 69 \\
\hline & & CIP 103228T & Bovine mastitis & 70 \\
\hline & & $\mathrm{Z2}$ & Veterinary & 71 \\
\hline & & A7 & Hen & 72 \\
\hline
\end{tabular}

* With the exception of strains CIP 55.120 (group G) and CIP 55.123 (group L).

DNA $^{12,13}$ and ribosomal DNA regions ${ }^{12}$ and DNA RFLP analysis with rarely cutting restriction endonucleases coupled with pulsed-field gel electrophoresis. ${ }^{14}$ These techniques can differentiate strains of different $M$ serotypes, and also epidemiologically distinct strains within a serotype. Random amplified polymorphic DNA analysis has been evaluated for typing group A streptococci. ${ }^{15}$

Enzyme electrophoresis is a powerful tool for differentiating bacterial species and distinguishing strains of the same species on the basis of their genetic relationships ${ }^{16-24}$ and was used recently to evaluate the genetic relationships among the oral streptococci, ${ }^{\mathbf{1 6}}$ to study clonal diversity of $S$. pyogenes causing toxicshock-like syndrome ${ }^{7}$ and to describe the $S$. pyogenes strains responsible for recurrent pharyngitis. ${ }^{25}$ The present work examined the usefulness of enzyme electrophoresis for both interspecies and intraspecies differentiation of pyogenic streptococci belonging to Lancefield groups A, C and G.

\section{Materials and methods}

\section{Bacterial strains}

The 101 strains tested, designated according to
Farrow and Collins, ${ }^{4}$ were distributed as follows: 44 strains of $S$. pyogenes, 25 of group G streptococci, 11 of "S. equisimilis", seven of $S$. dysgalactiae, four of $S$. canis, three of $S$. equi subsp. equi (S. equi) and seven of $S$. equi subsp. zooepidemicus ( $S$. zooepidemicus) (table I). Forty-one were reference strains and 60 were clinical isolates of human or animal origin, epidemiologically unrelated and originating from three French hospitals. For esterase analysis, 31 additional isolates of $S$. pyogenes were studied. The strains were identified on the basis of serological grouping (Streptococcal Grouping Kit, Oxoid) and biochemical tests (API 20 STREP, bioMérieux).

\section{Preparation of bacterial extracts}

Bacteria were grown for $18 \mathrm{~h}$ at $37^{\circ} \mathrm{C}$ with constant agitation in a buffered broth containing tryptone $0.5 \%$, yeast extract $0.25 \%, 20 \mathrm{mM}$ DL-threonine, $0.6 \mathrm{~mm} \mathrm{MgSO}, 0.03 \mathrm{~mm} \mathrm{MnSO}, 0.08 \mathrm{~mm} \mathrm{NaCl}$, $25 \mathrm{mM} \mathrm{NH}_{4} \mathrm{HCO}_{3}, 1.0 \mathrm{M} \mathrm{L}$-cysteine hydrochloride and glucose $0.4 \%$ in $40 \mathrm{~mm}$ potassium phosphate buffer. ${ }^{16}$ The bacterial growth was collected by centrifugation and washed with $60 \mathrm{~mm}$ Tris-glycine buffer, $\mathrm{pH} \mathrm{8.7,}$ resuspended in the same buffer and the cells were 
disrupted by intermittent sonication for $4 \mathrm{~min}$ at $4^{\circ} \mathrm{C}$. The crude extracts were stored at $-20^{\circ} \mathrm{C}$ until used.

\section{Electrophoresis}

Horizontal slab gel electrophoresis was performed by the method of $\mathrm{Uriel}^{26}$ in a composite polyacrylamide-agarose gel with a discontinuous Trisglycine buffer, $\mathrm{pH} 8 \cdot 7$, at constant voltage $(7 \mathrm{~V} / \mathrm{cm})$ until the bromophenol blue marker had run $13 \mathrm{~cm}$. The gel contained polyacrylamide $5 \%$ for analysis of nucleoside phosphorylase (NSP) and phosphoglucose isomerase (PGI) and polyacrylamide 7\% for analysis of lactate dehydrogenase (LDH), hydroxy-butyrate dehydrogenase (HBD) and adenylate kinase (ADK). The relative mobility $\left(\mathrm{M}_{\mathrm{F}}\right.$ value) is the distance moved by the enzyme band as a percentage of the distance moved by the dye front. $\mathrm{M}_{\mathrm{F}}$ values were compared by running the bacterial extracts side by side in the same gel.

\section{Specific staining procedures}

The six enzymes studied, LDH, NSP, PGI, HBD, $\mathrm{ADK}$ and esterases, were revealed on the gel by specific staining. LDH activity was detected by the method of Siciliano and Shaw. ${ }^{27}$ The staining methods for NSP, PGI, ADK and HBD were as described by Selander et $a .^{23}$ For NSP, PGI and ADK, the stain solution was applied to the gel in an agar overlay. Esterases were stained according to Uriel ${ }^{28}$ with the following specific substrates: $\alpha$ - and $\beta$-naphthyl acetates, $\alpha$ - and $\beta$-naphthyl propionates, $\alpha$ - and $\beta$ naphthyl butyrates and indoxyl acetate.

\section{Genetic diversity}

Genetic diversity at a locus among isolates was calculated as $h=1-\varepsilon x_{i}{ }^{2}[n /(n-1)]$, where $x_{i}$ is the frequency of the ith allele and $n$ is the number of isolates. ${ }^{23}$ Mean genetic diversity per locus $(\mathrm{H})$ is the arithmetic average of $h$ values for all loci.

\section{Statistical analysis}

The data were summarised in a two-way table of 101 rows, one for each strain, and 28 columns corresponding to the number of $\mathrm{M}_{\mathrm{F}}$ variants detected in all strains for five enzymes tested (LDH, NSP, PGI, HBD and ADK), in addition to a column for absence of detection of each enzyme. For each column, each strain was coded as a binary code: present $=1$ or absent $=0$. This table was used for a factorial analysis of correspondence (FAC) ${ }^{29}$ and a dissimilarity matrix was constructed for hierarchical clustering.

\section{Results}

\section{Detection of enzyme bands}

LDH gave a single, well-stained band with 73 strains. The remaining 28 strains, including all the $S$. zooepidemicus strains and two of the three $S$. equi
Table II. Number of alleles and genetic diversity (h) at five enzyme loci among the 101 pyogenic streptococcal strains

\begin{tabular}{ccc}
\hline Enzyme locus & Number of alleles & $\mathrm{h}$ \\
\hline LDH & 4 & 0.650 \\
NSP & 4 & $0 \cdot 273$ \\
PGI & 5 & $0 \cdot 268$ \\
HBD & 8 & 0.755 \\
ADK & 10 & 0.740 \\
\hline
\end{tabular}

strains, showed no detectable LDH band, although the LDH activity of these bacterial extracts measured biochemically was not significantly different from that of the other strains and are thus regarded as allozymes that are undetectable by electrophoresis. A single HBD band was detected in most strains, with the exception of $S$. equi and S. zooepidemicus which had two bands. Thirty-one strains, including all $S$. canis and " $S$. equisimilis" strains, had no HBD activity. Bands from $S$. pyogenes were well stained, but those from $S$. equi and $S$. zooepidemicus were less focused. The activity with group $\mathrm{G}$ streptococci was very weak and detection required overnight staining. NSP, PGI and ADK each gave a single well-stained band, with the exception of one strain of " $S$. equisimilis" for which no PGI was detected. Esterases were detected in all strains, and the number of bands varied from one to four. Most of the strains had a main band that stained intensely, with one or several faint bands. Since they all hydrolysed each of the seven synthetic substrates, the strains could not be characterised in terms of esterase type by their spectrum of activity towards these substrates. ${ }^{17,20}$

\section{Genetic heterogeneity and zymotypes}

LDH, NSP, PGI, HBD and ADK were polymorphic. The genetic diversity of these enzymes ranged from 0.268 for PGI to 0.755 for HBD (table II), with a mean genetic diversity of 0.537 . HBD gave a total of eight zymotypes and ADK produced 10, but the other enzymes were less variable. Differences in number and mobility of esterase bands led to the identification of 49 esterase electrophoretic patterns (EEPs) in the 101 isolates (fig. 1). Several EEPs were encountered more frequently, particularly EEP 1,2 and 3 which were found in six, nine and $10 \mathrm{~S}$. pyogenes strains, respectively. Reference strains and clinical isolates could not be separated by the electrophoretic pattern of their esterases. EEP20 and EEP22 were common to group G streptococci and "S. equisimilis", and EEP31 to $S$. dysgalactiae and " $S$. equisimilis". None of the EEPs found in $S$. pyogenes was found in the other species. Overall, the electrophoretic variations of the six enzymes gave a total of 72 distinct zymotypes in the 101 strains (table III).

\section{Species identification}

Projections of the strains on the plane F1, F2 (fig. 2) of the FAC accounted for $47.5 \%$ of the total variance 


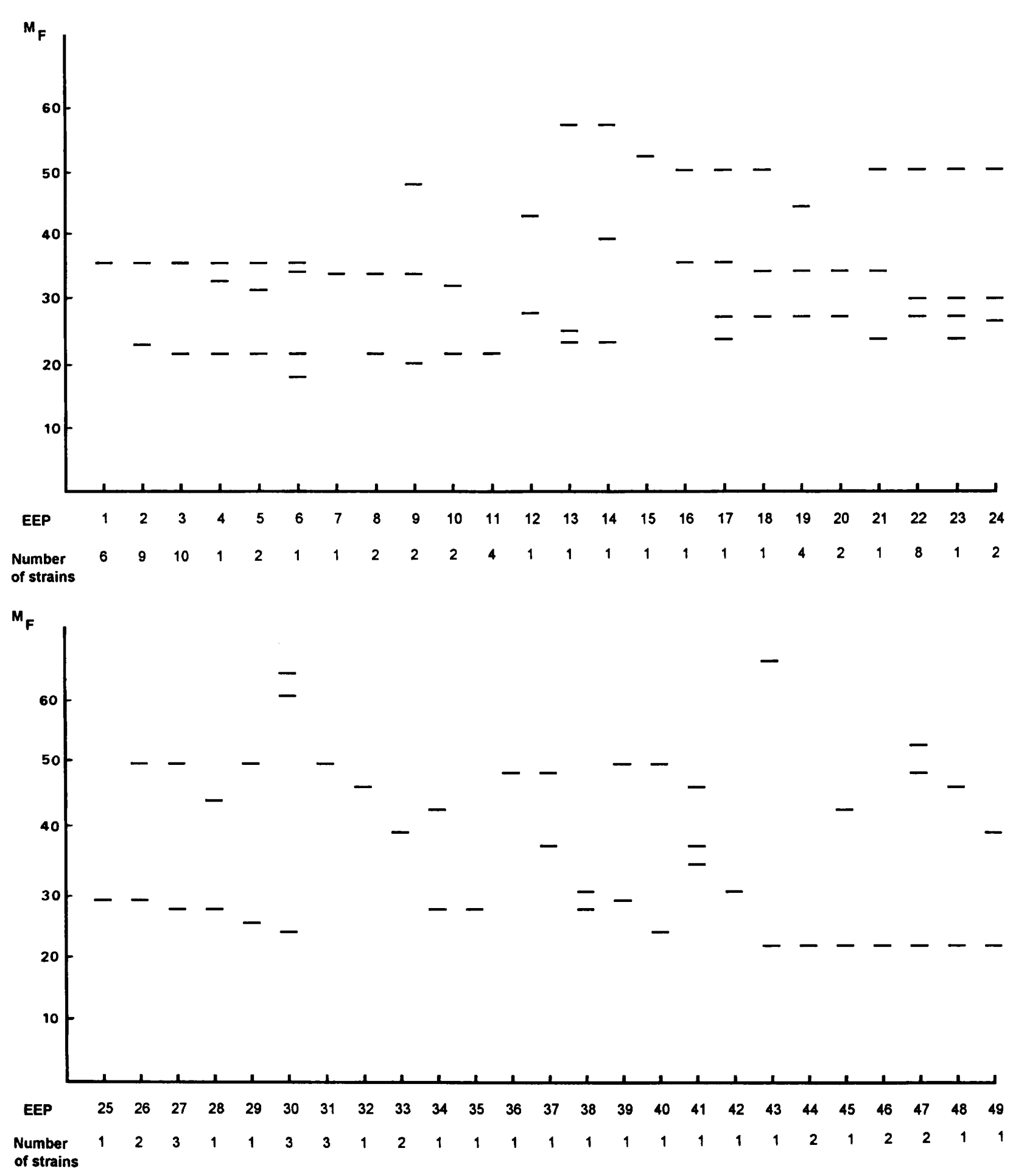

Fig. 1. Diagram of the esterase electrophoretic patterns (EEP) of 101 strains of pyogenic streptococci. S. pyogenes, EEP 1-15; group G streptococci, EEP 16-28; S. canis, EEP 29-30; S. dysgalactiae, EEP 31-35; "S. equisimilis", EEP 20, 22, 31, 36-42; S. equi, EEP 43-44; $S$. zooepidemicus, EEP 45-49.

and indicated that the $S$. pyogenes strains were distinguished from group G streptococci, $S$. dysgalactiae and " $S$. equisimilis" strains by the first axis, whereas the $S$. equi and S. zooepidemicus strains were differentiated by the positive values of the second axis. Projections of the electrophoretic variants on the plane indicated the principal features providing genetic species identification of pyogenic streptococci by enzyme polymorphism. Thus, the electrophoretic variants, no. 4 of ADK (ADK4), no. 3 of $\mathrm{LDH}$ (LDH3) and no. 3 of HBD (HBD3) were projected with the $S$. pyogenes strains. The dissimilarity between strains was used to construct a dendrogram (fig. 3), this indicated the correct classification of all strains within each of the four species distinguished by DNADNA hybridisation. ${ }^{18}$ Within the DNA homology group 4, S. equi and S. zooepidemicus were separated by their enzyme polymorphism, whereas in the DNA 
Table III. Zymotypes detected in 101 strains of pyogenic streptococci

\begin{tabular}{|c|c|c|c|c|c|c|c|c|c|}
\hline \multirow{2}{*}{$\begin{array}{l}\text { DNA homology } \\
\text { group }^{6}\end{array}$} & \multirow{2}{*}{ Species } & \multirow{2}{*}{$\begin{array}{l}\text { Number of } \\
\text { strains }\end{array}$} & \multicolumn{5}{|c|}{ Allele at the indicated enzyme locus* } & \multirow{2}{*}{$\mathrm{EEP} \dagger$} & \multirow{2}{*}{ Zymotype } \\
\hline & & & LDH & NSP & PGI & HBD & ADK & & \\
\hline \multirow[t]{31}{*}{1} & S. pyogenes & 1 & $0 \ddagger$ & 2 & 2 & 3 & 5 & 7 & 1 \\
\hline & & 1 & 0 & 2 & 2 & 3 & 4 & 5 & 2 \\
\hline & & 1 & 0 & 2 & 2 & 3 & 4 & 2 & 3 \\
\hline & & 2 & 0 & 2 & 2 & 3 & 4 & 3 & 4 \\
\hline & & 1 & 0 & 2 & 2 & 3 & 2 & 14 & 5 \\
\hline & & 2 & 0 & 2 & 2 & 3 & 2 & 2 & 6 \\
\hline & & 1 & 0 & 2 & 2 & 3 & 6 & 11 & 7 \\
\hline & & 1 & 0 & 2 & 2 & 3 & 1 & 2 & 8 \\
\hline & & 1 & 0 & 4 & 2 & 0 & 2 & 13 & 9 \\
\hline & & 1 & 0 & 2 & 2 & 0 & 2 & 3 & 10 \\
\hline & & 3 & 0 & 2 & 2 & 0 & 4 & 3 & 11 \\
\hline & & 1 & 0 & 2 & 2 & 0 & 4 & 9 & 12 \\
\hline & & 1 & 0 & 2 & 2 & 0 & 4 & 11 & 13 \\
\hline & & 1 & 3 & 2 & 2 & 0 & 4 & 8 & 14 \\
\hline & & 1 & 3 & 2 & 2 & 0 & 5 & 12 & 15 \\
\hline & & 1 & 3 & 2 & 2 & 3 & 5 & 3 & 16 \\
\hline & & 1 & 3 & 2 & 2 & 3 & 4 & 5 & 17 \\
\hline & & 1 & 3 & 2 & 2 & 3 & 4 & 2 & 18 \\
\hline & & 3 & 3 & 2 & 2 & 3 & 4 & 3 & 19 \\
\hline & & 1 & 3 & 2 & 2 & 3 & 4 & 11 & 20 \\
\hline & & 1 & 3 & 2 & 2 & 1 & 4 & 3 & 21 \\
\hline & & 1 & 3 & 2 & 2 & 1 & 4 & 8 & 22 \\
\hline & & 1 & 3 & 2 & 2 & 5 & 4 & 11 & 23 \\
\hline & & 1 & 3 & 2 & 2 & 3 & 2 & 6 & 24 \\
\hline & & 2 & 3 & 2 & 2 & 3 & 2 & 2 & 25 \\
\hline & & 6 & 3 & 2 & 2 & 3 & 2 & 1 & 26 \\
\hline & & 1 & 3 & 2 & 2 & 3 & 2 & 9 & 27 \\
\hline & & 1 & 3 & 2 & 2 & 0 & 2 & 4 & 28 \\
\hline & & 2 & 3 & 2 & 2 & 0 & 2 & 2 & 29 \\
\hline & & 1 & 3 & 2 & 2 & 0 & 7 & 10 & 30 \\
\hline & & 1 & 3 & 2 & 2 & 3 & 7 & 15 & 31 \\
\hline \multirow[t]{31}{*}{2} & "S. equisimilis" & 1 & 2 & 2 & 2 & 0 & 6 & 40 & 32 \\
\hline & S. dysgalactiae & 1 & 2 & 2 & 2 & 0 & 6 & 31 & 33 \\
\hline & Group G & 1 & 2 & 2 & 2 & 6 & 5 & 17 & 34 \\
\hline & streptococci & 1 & 2 & 2 & 2 & 6 & 5 & 18 & 35 \\
\hline & & 1 & 2 & 2 & 2 & 6 & 5 & 21 & 36 \\
\hline & & 1 & 2 & 2 & 2 & 6 & 5 & 23 & 37 \\
\hline & & 6 & 2 & 2 & 2 & 6 & 5 & 22 & 38 \\
\hline & & 1 & 2 & 2 & 2 & 6 & 5 & 24 & 39 \\
\hline & & 2 & 2 & 2 & 2 & 6 & 5 & 26 & 40 \\
\hline & & 3 & 2 & 2 & 2 & 6 & 5 & 27 & 41 \\
\hline & & 4 & 2 & 2 & 2 & 6 & 5 & 19 & 42 \\
\hline & & 1 & 2 & 2 & 2 & 6 & 5 & 28 & 43 \\
\hline & & 1 & 2 & 2 & 2 & 6 & 5 & 25 & 44 \\
\hline & & 1 & 0 & 2 & 2 & 6 & 5 & 16 & 45 \\
\hline & & 1 & 2 & 2 & 2 & 0 & 5 & 22 & 46 \\
\hline & & 1 & 2 & 2 & 2 & 0 & 5 & 24 & 47 \\
\hline & & 1 & 2 & 2 & 2 & 0 & 5 & 26 & 48 \\
\hline & S. dysgalactiae & 1 & 2 & 2 & 2 & 0 & 5 & 34 & 49 \\
\hline & & 1 & 2 & 2 & 2 & 0 & 5 & 35 & 50 \\
\hline & "S. equisimilis" & 2 & 2 & 2 & 2 & 0 & 5 & 20 & 51 \\
\hline & $\begin{array}{l}\text { Group G } \\
\text { streptococci }\end{array}$ & & & & & & & & \\
\hline & "S. equisimilis" & 1 & 2 & 2 & 2 & 0 & 5 & 38 & 52 \\
\hline & & 1 & 2 & 2 & 2 & 0 & 5 & 42 & 53 \\
\hline & & 1 & 2 & 4 & 2 & 0 & 5 & 41 & 54 \\
\hline & & 1 & 2 & 2 & 1 & 0 & 5 & 22 & 55 \\
\hline & & 1 & 2 & 2 & 0 & 0 & 5 & 31 & 56 \\
\hline & S. dysgalactiae & 1 & 2 & 2 & 2 & 1 & 5 & 31 & 57 \\
\hline & & 1 & 2 & 2 & 2 & 1 & 5 & 32 & 58 \\
\hline & "S. equisimilis" & 1 & 2 & 2 & 3 & 2 & 5 & 37 & 59 \\
\hline & & 1 & 2 & 2 & 3 & 2 & 5 & 36 & 60 \\
\hline & S. dysgalactiae & 2 & 2 & 2 & 3 & 3 & 5 & 33 & 61 \\
\hline 3 & S. canis & 1 & 0 & 3 & 2 & 0 & 3 & 29 & 62 \\
\hline & & 3 & 2 & 3 & 2 & 0 & 8 & 30 & 63 \\
\hline 4 & S. equi & 2 & 0 & 3 & 3 & 7 & 10 & 44 & 64 \\
\hline & & 1 & 1 & 3 & 3 & 7 & 10 & 43 & 65 \\
\hline
\end{tabular}


Table III (cont.)

\begin{tabular}{|c|c|c|c|c|c|c|c|c|c|}
\hline \multirow{2}{*}{$\begin{array}{l}\text { DNA homology } \\
\text { group }^{6}\end{array}$} & \multirow{2}{*}{ Species } & \multirow{2}{*}{$\begin{array}{l}\text { Number of } \\
\text { strains }\end{array}$} & \multicolumn{5}{|c|}{ Allele at the indicated enzyme locus* } & \multirow{2}{*}{$\mathrm{EEP} \dagger$} & \multirow{2}{*}{ Zymotype } \\
\hline & & & $\mathrm{LDH}$ & NSP & PGI & HBD & ADK & & \\
\hline & S. zooepidemicus & 1 & 0 & 4 & 3 & 7 & 8 & 47 & 66 \\
\hline & & 1 & 0 & 4 & 3 & 7 & 8 & 45 & 67 \\
\hline & & 1 & 0 & 4 & 3 & 7 & 8 & 46 & 68 \\
\hline & & 1 & 0 & 4 & 3 & 7 & 10 & 46 & 69 \\
\hline & & 1 & 0 & 4 & 3 & 7 & 10 & 48 & 70 \\
\hline & & 1 & 0 & 1 & 3 & 7 & 9 & 47 & 71 \\
\hline & & 1 & 0 & 4 & 4 & 4 & 10 & 49 & 72 \\
\hline
\end{tabular}

* Alleles are numbered consecutively in order of decreasing anodal mobility.

$\dagger$ Esterase electrophoretic pattern.

† No detectable enzyme activity.

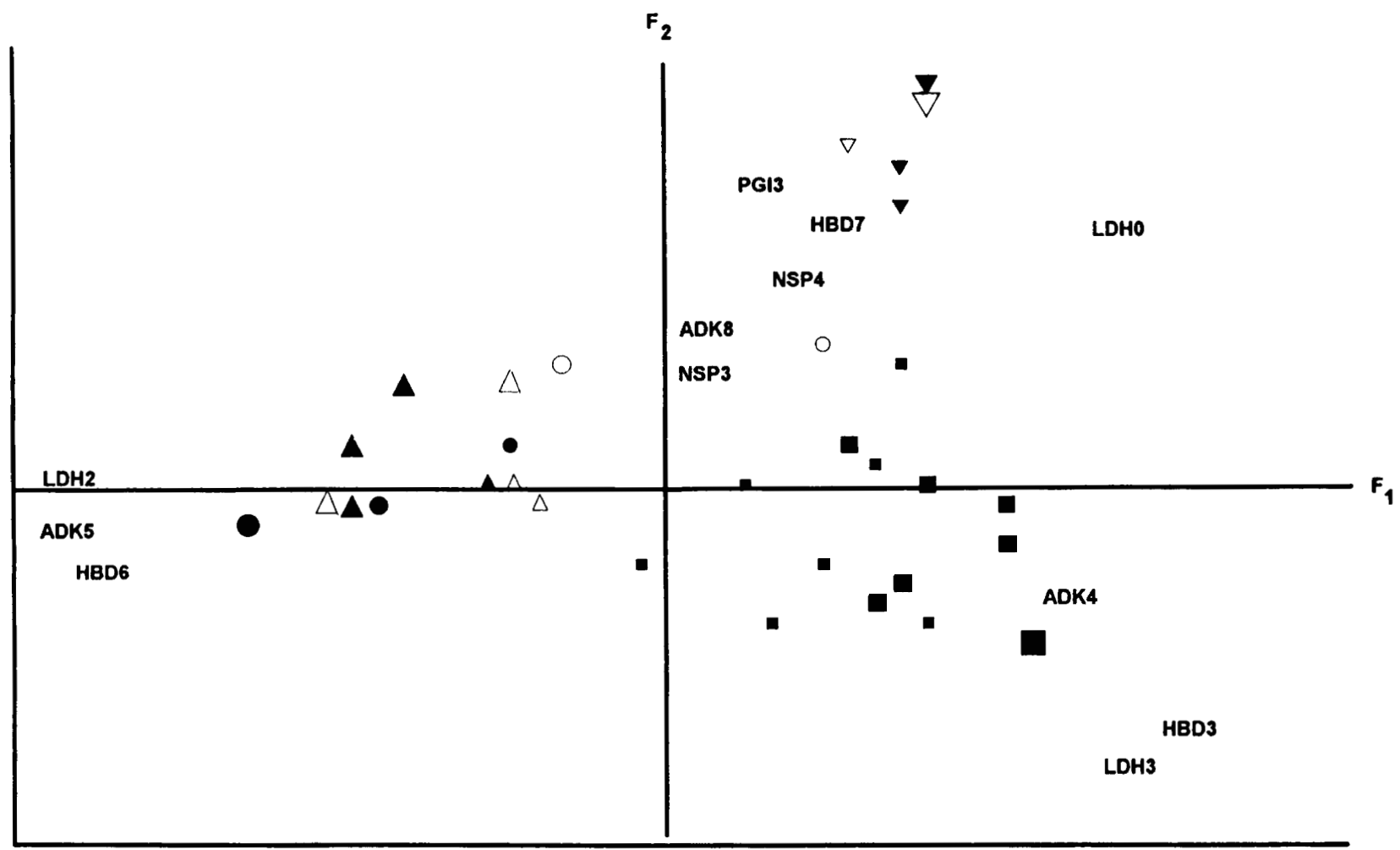

Fig. 2. Correspondence analysis of 101 pyogenic streptococci strains performed on the enzyme data. Projection of strains of $S$. pyogenes $(\boldsymbol{\square})$, group G streptococci $(\bigcirc), S$. dysgalactiae $(\triangle)$, "S. equisimilis" $(\mathbf{\Delta}), S$. canis $(\bigcirc), S$. equi $(\nabla)$ and $S$. zooepidemicus $(\nabla)$ and electrophoretic variants of lactate dehydrogenase (e.g., variant no. $3=\mathrm{LDH} 3$ ), nucleoside phosphorylase (NSP), phosphoglucose isomerase (PGI), hydroxybutyrate dehydrogenase (HBD) and adenylate kinase (ADK) on plane F1, F2. For clarity, the dimensions of the symbols vary with the number of strains projected on the same point of the plane, (e.g., for $S$. pyogenes $\mathbf{\square}, 1$ strain; $\mathbf{\square}, 2-10$ strains; $\square>10$ strains).

homology group 2, group $\mathrm{G}$ streptococci, " $S$. equisimilis" and $S$. dysgalactiae were not clearly separated.

\section{Strain typing}

LDH, NSP, PGI, HBD and ADK analysis led to the identification of 18 zymotypes for $S$. pyogenes, three for group G streptococci and six for "S. equisimilis". Fifteen EEPs were delineated among the 44 S. pyogenes strains. Eight other EEPs were found among the 31 additional isolates for which esterases alone were studied, providing a total of 23 EEPs in the $75 \mathrm{~S}$. pyogenes strains (data not shown). Thirteen EEPs were delineated among group $\mathrm{G}$ streptococci strains and 10 among " $S$. equisimilis" strains. Thirty-one zymotypes were found for $S$. pyogenes, 14 for group G streptococci and 11 for " $S$. equisimilis" (table IV) when the analysis of esterases and other enzymes was combined.

\section{Discussion}

Analysis of enzyme electrophoretic polymorphism has been shown to be of taxonomic value in dealing with gram-negative bacilli and oral streptococci, for 


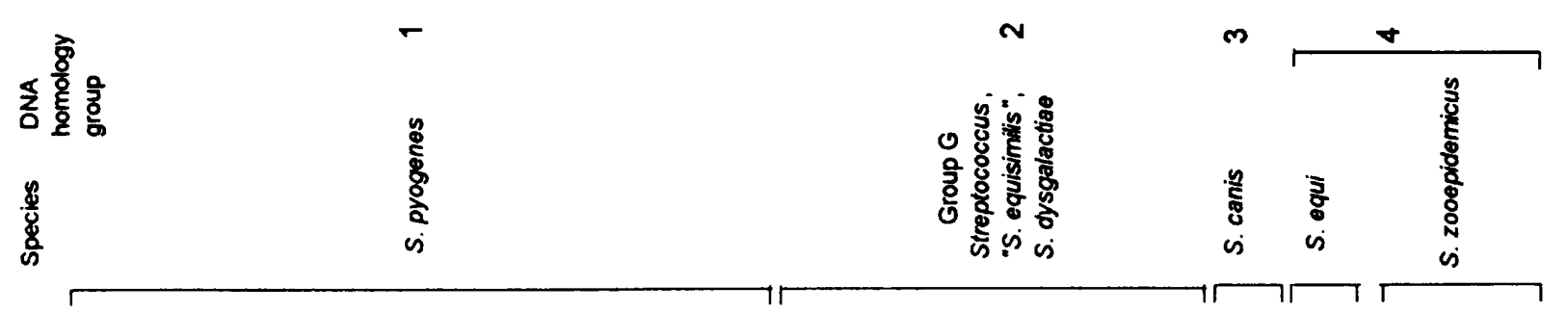

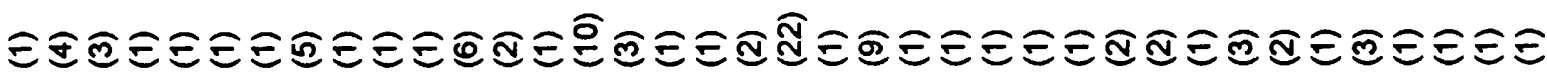

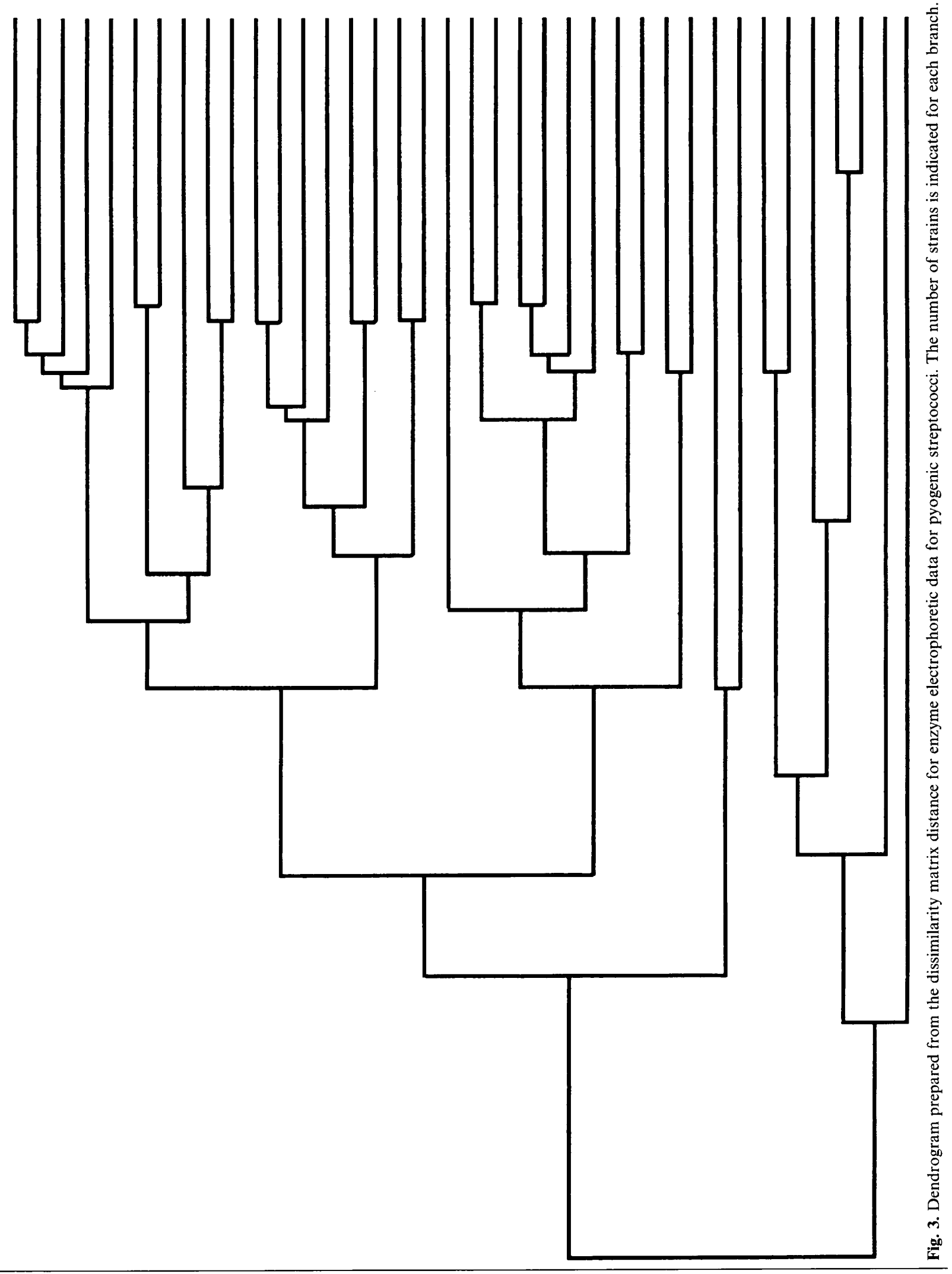


Table IV. Number of zymotypes detected among 101 strains of pyogenic streptococci

\begin{tabular}{|c|c|c|c|c|c|c|c|}
\hline $\begin{array}{l}\text { Species } \\
\text { (number of strains) }\end{array}$ & LDH & NSP & PGI & HBD & ADK & Esterase & Enzyme* \\
\hline S. pyogenes $(44)$ & 2 & 2 & 1 & 4 & 6 & 15 & 31 \\
\hline Group G streptococci (25) & 2 & 1 & 1 & 2 & 1 & 13 & 14 \\
\hline "S. equisimilis" (11) & 1 & 2 & 4 & 2 & 2 & 10 & 11 \\
\hline S. dysgalactiae (7) & 1 & 1 & 2 & 3 & 3 & 5 & 6 \\
\hline S. canis (4) & 2 & 1 & 1 & 1 & 2 & 2 & 2 \\
\hline S. equi (3) & 2 & 1 & 1 & 1 & 1 & 2 & 2 \\
\hline S. zooepidemicus (7) & 1 & 2 & 2 & 3 & 3 & 5 & 7 \\
\hline All strains (101) & 4 & 4 & 5 & 8 & 10 & 49 & 72 \\
\hline
\end{tabular}

* Number of zymotypes resulting from the combined analysis of six enzymes.

which there is a good correlation with DNA analysis. ${ }^{16,18,19,23,24}$ Similarly, the results of the present study on pyogenic streptococci are consistent with those obtained by DNA hybridisation. Thus, enzyme electrophoretic polymorphism showed that $S$. $d y s-$ galactiae, "S. equisimilis" and group G streptococci were closely related, and also $S$. equi and $S$. zooepidemicus, whereas strains of $S$. pyogenes were clearly distinguished from the other strains. The results shown as a FAC (fig. 2) illustrate the differentiation of these groups and indicate the main electrophoretic variants of each group. Four major branches are identified (fig. 3 ), each of which includes all the strains belonging to the same DNA homology group; the genetic relationships between those groups are similar to those indicated by the dendrogram based on DNA-DNA hybridisation. ${ }^{6}$ Statistical analysis was performed with electrophoretic polymorphism data for five of the six enzymes studied (LDH, NSP, PGI, HBD and ADK). Esterases were not included in this because of their high degree of intraspecies polymorphism and the absence of biochemical differentiation among these enzymes. This limited their taxonomic value for pyogenic streptococci.

The present work establishes the efficacy of enzyme electrophoretic polymorphism analysis for typing pyogenic streptococci. The high degree of polymorphism of esterases allowed the identification of 15 zymotypes among 44 strains of $S$. pyogenes, 13 in 25 group strains of $\mathrm{G}$ streptococci and 10 in 11 strains of " $S$. equisimilis". The other enzymes were less polymorphic and the smaller variation in their mobility within each species limits their usefulness as epidemiological markers. However, the combination of esterase analysis with that of the other enzymes increased the number of zymotypes detected among 44 strains of $S$. pyogenes from 15 to 31 (table IV). The results were less impressive for group $\mathrm{G}$ streptococci, for which esterase typing efficiency was little improved when combined with analysis of other enzymes. However, all strains of " $S$. equisimilis" and $S$. zooepidemicus were differentiated by this technique.

Enzyme electrophoretic polymorphism analysis has been used by Musser et al. to estimate genetic diversity among $S$. pyogenes strains responsible for toxic-shocklike syndrome. ${ }^{7}$ They studied 108 isolates and 12 enzymes, including the six enzymes used in the current work and found approximately the same number of zymotypes. This result can be explained by the presence of two related clones that accounted for nearly half of the strains. The number of patterns differentiated by random amplified polymorphic DNA analysis ${ }^{15}$ among 160 unrelated isolates of $S$. pyogenes was identical to the number of zymotypes found in this study. However, only one primer was selected, and the discriminatory power of this method could be improved by the use of a combination of primers.

The present study shows that enzyme electrophoresis is a valuable method for the differentiation of species of pyogenic streptococci and the estimation of the genetic relationships between them. It supports the taxonomic results obtained by DNA hybridisation and confirms the poor species specificity of the Lancefield serological classification. However, enzyme electrophoresis, which surveys the products of individual gene loci, provides additional information on the genetic diversity within species, whereas DNA hybridisation is usually performed with only a small number of reference strains. Thus the analysis of the polymorphism of six enzymes, esterases in particular, is an effective technique for typing strains of pyogenic streptococci.

We thank Drs C. Bizet and T. Horaud for providing reference strains, Mrs C. Gaillard and N. Hautier for technical assistance, Mrs C. Gillet for secretarial assistance and Dr O. Parkes for editorial help.

\section{References}

1. Lancefield RC. A serological differentiation of human and other groups of hemolytic streptococci. J Exp Med 1933; 57: 571-595.

2. Jones D. Composition and differentiation of the genus Streptococcus. In: Skinner FA, Quesnel LB (eds) Streptococci. coccus. J Gen Microbiol 1983; 129: 565-597.

4. Farrow JAE, Collins MD. Taxonomic studies on streptococci of serological groups $\mathrm{C}, \mathrm{G}$ and $\mathrm{L}$ and possibly related taxa. Syst Appl Microbiol 1984; 5: 483-493. 
5. Kilpper-Bälz R, Schleifer KH. Nucleic acid hybridization and cell wall composition studies of pyogenic streptococci. FEMS Microbiol Lett 1984; 24: 355-364.

6. Schleifer KH, Kilpper-Bälz R. Molecular and chemotaxonomic approaches to the classification of streptococci, enterococci and lactococci: a review. Syst Appl Microbiol 1987; 10: $1-19$.

7. Musser JM, Hauser AR, Kim MH, Schlievert PM, Nelson K, Selander RK. Streptococcus pyogenes causing toxic-shocklike syndrome and other invasive diseases: clonal diversity and pyrogenic exotoxin expression. Proc Natl Acad Sci USA 1991; 88: 2668-2672.

8. Schwartz B, Facklam RR, Breiman RF. Changing epidemiology of group A streptococcal infection in the USA. Lancet 1990; 336: 1167-1171.

9. Swift HF, Wilson AT, Lancefield RC. Typing group A hemolytic streptococci by $M$ precipitin reactions in capillary pipettes. $J$ Exp Med 1943; 78: 127-133.

10. Efstratiou A. Outbreaks of human infection caused by pyogenic streptococci of Lancefield groups C and G. J Med Microbiol 1989; 29: 207-219.

11. Bouvet A, Geslin P, Kriz-Kuzemenska P, Blanc V, Devine C, Grimont F. Restricted association between biotypes and serotypes within group A streptococci. J Clin Microbiol 1994; 32: 1312-1317.

12. Bingen $\mathrm{E}$, Denamur $\mathrm{E}$, Lambert-Zechovsky $\mathrm{N}$ et al. Mother-toinfant vertical transmission and cross-colonization of Streptococcus pyogenes confirmed by DNA restriction fragment length polymorphism analysis. J Infect Dis 1992; 165: $147-150$.

13. Cleary PP, Kaplan FL, Livdahl C, Skjold S. DNA fingerprints of Streptococcus pyogenes are M type specific. J Infect Dis 1988; 158: 1317-1323.

14. Single LA, Martin DR. Clonal differences within M-types of the group A Streptococcus revealed by pulsed field gel electrophoresis. FEMS Microbiol Lett 1992; 91 : 85-90.

15. Seppälä $H, H e$ Q, Österblad M, Huovinen P. Typing of group A streptococci by random amplified polymorphic DNA analysis. J Clin Microbiol 1994; 32: 1945-1948.

16. Gilmour MN, Whittam TS, Killian M, Selander RK. Genetic relationships among the oral streptococci. J Bacteriol 1987; 169: 5247-5257.

17. Goullet P. An esterase zymogram of Escherichia coli. J Gen Microbiol 1973; 77: 27-35.
18. Goullet P, Picard B. Characterization of Enterobacter cloacae and E. sakazakii by electrophoretic polymorphism of acid phosphatase, esterases, and glutamate, lactate and malate dehydrogenases. J Gen Microbiol 1986; 132 : 3105-3112.

19. Goullet P, Picard B. Characterization of Yersinia enterocolitica, $Y$. intermedia, $Y$. aldovae, $Y$. frederiksenii, $Y$. kristensenii and $Y$. pseudotuberculosis by electrophoretic polymorphism of acid phosphatase, esterases and glutamate and malate dehydrogenases. J Gen Microbiol 1988; 134: 317-325.

20. Goullet P, Picard B. The electrophoretic polymorphism of bacterial esterases. FEMS Microbiol Rev 1995; 16: 7-31.

21. Picard B, Goullet P. Epidemiological complexity of hospital aeromonas infections revealed by electrophoretic typing of esterases. Epidemiol Infect 1987; 98: 5-14.

22. Picard B, Goullet P. Epidemiological typing of Acinetobacter strains by esterase electrophoresis. FEMS Microbiol Lett 1990; 72: 229-234.

23. Selander RK, Caugant DA, Ochman H, Musser JM, Gilmour MN, Whittam TS. Methods of multilocus enzyme electrophoresis for bacterial population genetics and systematics. Appl Environ Microbiol 1986; 51 : 873-884.

24. Selander RK, Musser JM, Caugant DA, Gilmour MN, Whittam TS. Population genetics of pathogenic bacteria. Micro Pathog 1987; 3: 1-7.

25. Musser JM, Gray BM, Schlievert PM, Pichichero ME. Streptococcus pyogenes pharyngitis: characterization of strains by multilocus enzyme genotype, $\mathrm{M}$ and $\mathrm{T}$ protein serotype, and pyrogenic exotoxin gene probing. J Clin Microbiol $1992 ; 30: 600-603$.

26. Uriel J. Méthode d'électrophorèse dans des gels d'acrylamideagarose. Bull Soc Chim Biol 1966; 48: 969-982.

27. Siciliano $M$, Shaw $C R$. Separation and visualization of enzymes on gels. In: Smith I (ed) Chromatographic and electrophoretic techniques, 4th edn. Chicago, Yearbook Medical Publishers. 1976: 185-209.

28. Uriel J. Caractérisation des cholinestérases et d'autres estérases carboxyliques après électrophorèse et immunoélectrophorèse en gélose (application à l'étude des estèrases du sérum humain normal). Ann Inst Pasteur 1961; 101: 104-119.

29. Lebart L, Morineau A, Warwick KM. Multivariate descriptive analysis: correspondence analysis and related techniques for large matrices. New York, Wiley-Interscience. 1984: 231. 